\title{
Transferências de plantas em uma perspectiva histórica: o estado da discussão*
}

\author{
William Beinart e Karen Midleton \\ Tradução: Henrique Bertulani \\ Revisão técnica e edição: José Augusto Valladares Pádua \\ e Maria Aparecida Rezende Mota
}

\section{Introdução}

As plantas têm tido um papel central na história mundial. O crescimento demográfico humano na longa duração, assim como o desenvolvimento de sociedades complexas, tem sido frequentemente ligado à domesticação de plantas e animais. A popular síntese produzida recentemente por Jared Diamond coloca a domesticação de espécies selvagens como a primeira e principal etapa necessária ao início da intensificação da produção agrícola. ${ }^{1}$ Igualmente importante na história mundial tem sido a transferência de animais e plantas das áreas de origem para novas regiôes. Essas transferências têm sido fundamentais como facilitadoras de importantes processos de expansão de sociedades, complexos agrários e impérios. É provável que a domesticação de número limitado de vegetais e culturas alimentares realmente essenciais tenha sido, originalmente, fortemente localizada. Talvez seja correto dizer, portanto, que a maior parte do desenvolvimento agrícola foi dependente das transferências de plantas. Mesmo nos sistemas agrícolas, tais como existem no Oriente Médio, na China, nas Américas e em bolsões da África, ainda parcialmente baseados em plantas domesticadas localmente (trigo, arroz, milho e painço, respectivamente), o alastramento regional dessas culturas requer uma explicação.

Os complexos agrários que agora estão entre os mais produtivos do mundo, no norte da Europa, América do Norte e hemisfério sul, resultaram da migração ou adoção de uma ampla variedade de espécies de plantas, totalmente novas àquelas áreas, em tempos relativamente recentes. Como Alfred Crosby argumentou, em seu livro Ecological Imperialism, ${ }^{2}$ é difícil conceituar adequadamente o imperialismo europeu sem um entendimento das plantas e animais que o facilitaram e lhe deram forma.

A partir desse argumento surgem difíceis questôes historiográficas. Por um lado, as transferências de espécies durante a era imperial estiveram intimamente conectadas com formações sociais europeias expansionistas e capitalistas, assim como com as migraçóes, mercados, tecnologias e ciências que elas geraram. O conhecimento europeu sobre as qualidades das plantas, por sua vez, extraiu e sistematizou conhecimentos locais. Por outro lado, as propriedades das espécies em si mesmas, desde a cana-de-açúcar nos trópicos às ovelhas nas planícies antipodais, desempenharam um papel essencial na moldagem do padrão, do grau e do sucesso das transferências. Os impérios na América tropical tomaram forma não apenas com base no capitalismo, no poder marítimo e no desenvolvimento do sombrio comércio de escravos no Atlântico, mas também das oportunidades e restrições inerentes às características botânicas da cana-de-açúcar. As colônias de povoamento na Austrália, Nova Zelândia, África do Sul, Argentina e Uruguai foram profundamente afetadas por sua adequação aos animais domesticados a partir do hemisfério norte. É certo que os limites geográficos para a adaptação de espécies domesticadas foram enormemente estendidos pela aplicação de investimentos e conhecimento humano. Uma análise de tal adaptabilidade, no entanto, requer o auxílio de enfoques ecológicos e científicos, assim como sociais.

\footnotetext{
* Plant transfers in historical perspective: a review article foi publicado em Environment and History (vol. 10, n. 1, 2004). O Comitê Editorial de Topoi agradece aos autores e editores a autorização para publicar a tradução.
} 
Ao revisar uma pequena série de leituras a respeito de um assunto tão vasto, este trabalho coloca a pergunta sobre como podemos alcançar generalizações analíticas sobre as transferências de plantas. Ele exemplifica algumas das linhas que têm sido exploradas e indica outras que podem ser seguidas com proveito. Ele considera uma variedade de trabalhos recentes que enriquecem enormemente o nosso entendimento destes processos, mas que raramente são examinados em conjunto. Apesar do nosso interesse se concentrar aqui nas plantas em vez dos animais, reconhecemos que a transferência de ambos, sem contar os insetos e germes, foi por vezes intimamente conectada. O Jardin d'essai em Argel, por exemplo, apesar de ser uma instituição dedicada à horticultura, realizou experiências com combinações de insetos e suas plantas hospedeiras: bichos da seda e amoreiras, insetos de cochonilha e peras espinhosas. ${ }^{3}$

Nosso foco está concentrado em quatro questões entrelaçadas. Em primeiro lugar, o quão útil é a ideia de Crosby a respeito do imperialismo botânico e ecológico? Tem havido um padrão global de transferência de plantas de uma região para a outra e, se realmente ocorreu, como pode ser explicado? A assimetria tem um embasamento ecológico? As espécies fortes têm emergido de regióes específicas do mundo? Há regiōes sucessíveis à transformação rápida de sua flora indígena? Ou são os padrões geográficos assimétricos de transferência, caso esses possam ser detectados, melhor explicados a partir de estruturas culturais e de economia política?

Em segundo lugar, a literatura histórica focaliza o papel dos especialistas científicos, sobretudo cientistas botânicos dentro da Europa, assim como das instituiçôes para as quais eles trabalharam. Por dedução, assim como por argumentação direta, ela sugere que eles tiveram um lugar importante na história das transferências de plantas. Mas como devemos conceber o seu papel em relação ao das práticas mais informais e do conhecimento local? Poderíamos usar os argumentos de Diamond sobre a domesticação como uma analogia: este foi um processo muito diversificado, resultando de uma multiplicidade de experimentos e práticas diárias, ao invés de resultar de grandes "descobertas" facilmente datáveis.

Em terceiro lugar, é possível fazer uma distinção proveitosa entre a atuação humana na transferência e outros tipos de alastramento de plantas? Em que momento uma transferência intencional aparentemente controlada se torna uma invasão? Qual é a fronteira entre as plantas úteis e aquelas vistas como ervas daninhas?

Em quarto lugar, como corolário, existem pontos gerais a serem feitos em relação à aceitação e ao encorajamento da mudança botânica e da introdução de plantas por parte das sociedades? Quais são as forças que operam a favor ou contra a aceitação de transferências de plantas? E como a experiência africana neste campo contribui para a análise de modelos assimétricos?

Cientistas e historiadores, até mesmo aqueles que se definem como historiadores ambientais, tendem a adotar diferentes caminhos na resposta para essas perguntas. Os cientistas estão interessados principalmente nas características específicas das espécies de plantas e dos habitats naturais sujeitos a transferências ou invasões biológicas. Para a maioria dos historiadores, se trata quase do oposto. Eles tendem a ver a atuação humana como o principal fator, e estão menos preocupados com as oportunidades e restrições inerentes às características de plantas específicas. ${ }^{4}$

Mas seria errônea uma simplificação excessiva. Cientistas, como Diamond e Flannery, escreveram trabalhos ambiciosos e bem informados, extraindo informações de uma variedade de fontes históricas e adotando uma visão global do processo histórico. Eles tentam responder sistematicamente questôes sobre o desenvolvimento das culturas humanas e sua interface com o ambiente natural no longo prazo. Historiadores do meio ambiente, por sua vez, estão prestando cada vez mais atenção às disciplinas das ciências naturais e à pesquisa científica - pelo menos à pesquisa feita no passado. ${ }^{5}$ No nível teórico, Edward O. Wilson, entre outros, advoga por uma unificação dos enfoques científicos e humanistas. ${ }^{6}$ Todavia, a respeito das transferências de plantas, as literaturas científica e histórica ainda permanecem em grande medida separadas. E na prática é difícil aproximar as diferentes metodologias e prioridades de pesquisa estabelecidas pela ciência e pela história. 
Este ensaio de síntese originou-se de um projeto comparativo sobre a história das espécies mesoamericanas de opuntia (pera espinhosa ou pera de cacto) em Madagascar e na África do Sul. Apesar de não focalizarmos as espécies de opuntia nesse artigo, seu alastramento para nossas áreas de investigação, e para outro ambientes "mediterrâneos" e semiáridos, deu forma a muitas das perguntas que fazemos. As espécies de opuntia viajaram em múltiplas direções durante a era imperial, contra a corrente dos fluxos identificados por Crosby. Apesar de espécies de opuntia terem sido normalmente transferidas de maneira deliberada, algumas também manifestaram capacidade para se alastrar rapidamente para além das zonas designadas pelos humanos para sua fixação. Apesar de algumas espécies terem sido consideradas úteis, fornecendo cercados, forragem para animais e frutas para consumo humano, ocasionalmente as peras espinhosas foram condenadas como ervas perniciosas e invasoras. Os trajetos da opuntia nos alertam para os aspectos multifacetados da transferência das plantas, para a interação das atividades humanas e não humanas, e para a dificuldade em distinguir plantas domesticadas, selvagens e daninhas.

\section{Os fluxos das plantas: podem ser feitas generalizações?}

Crosby afirma que espécies exportadas da Eurásia, incluindo plantas selvagens e domesticadas, assim como animais e germes, não só auxiliaram as colônias de povoamento como também provaram ser mais poderosas que aquelas que se originaram nas Américas e na Australásia. Ele estabelece uma distinção forte entre a história profunda dos "velhos mundos" interconectados através dos continentes da Ásia, da Europa e, em menor escala, da África, e os continentes isolados do "novo mundo". E ele vê um claro fluxo de espécies de plantas dos primeiros para os segundos espaços.

Um grande número de plantas do "velho mundo" aclimatou-se nas Américas. Aproximadamente 50\% das ervas daninhas presentes nos espaços agrícolas dos Estados Unidos, 258 ao todo, e 60\% das presentes no Canadá, são provenientes da Eurásia, sendo a maioria de origem europeia. ${ }^{7}$ Em contraste, ele argumenta, relativamente poucas espécies americanas estabeleceram-se na Europa, na Austrália e na Nova Zelândia, demonstrando um padrão similar, existindo uma sobreposição significativa entre as ervas daninhas de todas essas regiōes.

Charles Darwin, reconhecendo essa assimetria, provocou um botânico americano: "Será que não fere seu orgulho yankee... que nós os superemos tão fortemente?"; seu correspondente concordou a respeito das "estrangeiras intrusivas, pretensiosas e autoconfiantes". ${ }^{8}$ Crosby dá vívidos exemplos de espécies autoalastradas que tiraram proveito das paisagens europeizadas e as transformaram de forma ainda mais intensa. Algumas foram consideradas úteis, como o trevo branco no México, o gerânio de caule vermelho na Califórnia, e o capim azul do Kentucky no leste dos Estados Unidos; algumas foram destrutivas, como o cardo na Argentina. Sua noção de imperialismo das plantas se expressa através de um ímpeto metafórico: "O sol nunca se põe no império do dente-de-leão". Ele vê a capacidade de rápida reprodução como um fator no sucesso das plantas europeias, sendo a similaridade do clima, o outro fator. ${ }^{9}$

Se o clima foi um fator-chave, poderíamos então esperar um intercâmbio mais recíproco. Sobre a ideia de que as plantas europeias são colonizadoras mais poderosas, pode-se encontrar uma fundamentação indireta em algumas sínteses científicas. Cronk e Fuller, no livro Plant invaders, também invocam o contraste entre os "velhos" e os "novos" mundos, mas com base em uma escala de tempo geológica. ${ }^{10}$ Grande parte do norte da Europa estava até recentemente coberto por geleiras. Seus solos foram expostos de maneira mais recente, sendo em geral mais rico para o crescimento de plantas. As áreas permanentemente cobertas por geleiras eram móveis, dependendo de mudanças climáticas no longo prazo. Eles sugerem que para lidar com esse "deslocamento das áreas congeladas", algumas plantas desenvolveram estratégias invasoras e oportunistas. A seleção natural, nesta fronteira de congelamento móvel, favoreceu as plantas que se reproduziam e se alastravam rapidamente. Apesar de enfatizarem esses fatores no que se refere à aparente falta de plantas invasoras nessas regiões temperadas e frias, uma vez que as 
plantas endêmicas são "inerentemente resistentes", tais características podem ter dado à flora europeia algumas vantagens na expansão para novos ambientes.

Um apoio para esse tipo de análise pode ser encontrado nos trabalhos de Tim Flannery sobre a história ambiental da Austrália. ${ }^{11}$ Ele desafia os conceitos de "velho" e de "novo" mundo, não só pelo fato de serem culturalmente carregados. Examinando o tema de um ponto de vista geológico e botânico, Flannery prefere inverter a terminologia. Geologicamente, o hemisfério sul, e a Austrália em especial, são o mundo mais antigo, e não o mundo mais novo. Seus solos expostos por um tempo muito longo tornaram-se drenados, erodidos e pobres. Um mundo caracterizado pela pobreza de recursos. Os antigos mamíferos da Austrália tendiam a ser menores do que aqueles de outros lugares. Muitas espécies de plantas australianas (e este argumento poderia ser aplicado igualmente à África do Sul e ao sul de Madagascar, que são semiáridos) eram adaptadas à escassez. Elas ficaram restritas a áreas altamente específicas e não se alastraram com facilidade.

Cronk e Fuller basearam-se em explicaçôes sociais, além das ecológicas, para entender a aparente assimetria nas invasões de plantas: séculos de intenso uso e gerenciamento ambiental na Europa, como também a falta de "áreas selvagens", podem ter diminuído as chances de espécies estrangeiras se estabelecerem na região. Um argumento corolário, que eles não exploram, seria o de que a dizimação dos indígenas americanos auxiliou na mudança da vegetação local. ${ }^{12}$ No ponto anterior, porém, eles também notam a possibilidade contrária, que zonas mais quentes possam ser particularmente propensas à colonização de espécies exóticas. Plantas advindas de áreas onde há fortes congelamentos no inverno, assim como de outras regiôes subtropicais, podem prosperar em condições mais quentes. Em contraste, as plantas provenientes de áreas livres de congelamento têm pouca probabilidade de sobreviver onde há congelamentos frequentes, especialmente quando acompanhados por longos períodos de baixa temperatura. As ilhas livres de congelamento, como o Havaí e aquelas dotadas de maior precipitação como as Canárias e a Madeira, têm provido habitats particularmente hospitaleiros. Algumas extensões litorâneas da África do Sul e da Austrália também compartilham essas características e têm sido botanicamente permeáveis.

Estes argumentos podem dar substância às conclusões impressionistas de Crosby. No entanto, precisamos ser cuidadosos ao perguntar como o fluxo direcional pode ser avaliado. Será o indicador básico o número de espécies transferidas? Ou será o número de espécies que se tornam úteis, se naturalizam ou se tornam invasoras? Será a área coberta por plantas exóticas, mesmo sendo em menor quantidade? Será o volume de produção das diferentes culturas transferidas? Serão necessários critérios quantitativos para melhor abordar este assunto? Será que devemos tentar identificar a extensão dos impactos sociais? Quais são as regiões e os períodos relevantes?

Mesmo no período entre 1500-1900, Crosby sugere que a transferência de plantas pode ter sido mais equilibrada. Navios navegavam em ambas as direções nas primeiras fases da expansão europeia, havia um retrofluxo significativo. Os agentes dos impérios europeus estavam muito atentos ao potencial das plantas. Muitas plantas foram deliberadamente trazidas dos trópicos e das zonas temperadas do hemisfério sul. A transferência acidental, além disso, sempre foi uma possibilidade. É possível identificar colonizadoras bem-sucedidas que vieram dos "novos" mundos, incluindo as zonas semiáridas onde os solos estavam expostos por um longo período. O eucalipto, fortemente adaptado às condiçôes específicas da Austrália, floresceu em outros lugares - seja em plantações, ou por autoalastramento naturalizado - incluindo áreas onde poucas (ou nenhuma) árvores nativas cresceriam (Crosby admite essa exceção). ${ }^{13}$ Os pinheiros norte-americanos estão amplamente difundidos. As peras espinhosas de ambientes americanos semiáridos, aparentemente pouco promissores, têm se mostrado altamente adaptáveis ao Mediterrâneo, ao sul da Ásia, ao oceano Índico e a partes da África e Austrália. Em alguns lugares elas se tornaram invasoras.

Aclimataçôes de culturas ameríndias tiveram um impacto dramático nas economias do "velho mundo" e em suas histórias sociais, como Crosby mais tarde reconheceu. ${ }^{14} \mathrm{O}$ quadro se torna mais complexo quando a África é considerada parte do "velho mundo" - e os fluxos ocorrendo no interior do hemisfé- 
rio sul são levados em conta. A África subsaariana passou a depender nos últimos três séculos de importantes culturas domesticadas advindas do "novo mundo". Se um leque mais amplo de alimentos e plantas úteis, ao invés de algumas poucas culturas básicas, for levado em consideração, adotando-se uma perspectiva global e não apenas europeia, teremos um fluxo de plantas mais multidirecional. Plantas americanas como o milho, a batata, a mandioca, a batata-doce, o tabaco, algumas variedades de vagens, o amendoim, o cacau, o abacate, a cinchona [quina], a pimenta-malagueta, a borracha, o agave, a prosópis [alfarroba], assim como também as peras espinhosas, são importantes e amplamente difundidas. É difícil imaginar espécies que tenham tido mais impacto social e culinário do que a batata na Europa. ${ }^{15}$ Um argumento parecido poderia ser feito com o milho na África e a pimenta malagueta na Índia.

Análises baseadas em uma escala de tempo mais longa podem gerar questionamentos adicionais. Nos últimos milênios ocorreram importantes movimentos de plantas dentro do "velho mundo": do Oriente Médio para grande parte do resto do mundo de clima temperado; do Mediterrâneo para o norte da Europa; assim como as transferências de arroz, cana-de-açúcar, frutas cítricas e bananas a partir do leste da Ásia. Os impérios árabes tiveram um papel-chave como intermediários nesse processo, disseminando o cultivo da cana-de-açúcar para as fronteiras setentrionais do Mediterrâneo. ${ }^{16}$ Mesmo se for analiticamente útil considerar a Eurásia como sendo uma zona única no que se refere aos padrões de doenças, é muito menos útil fazer o mesmo com respeito a plantas.

Se a cronologia se estender ao presente, incluindo-se jardins, casas e viveiros, a Europa pode ser considerada uma receptora no balanço líquido das transferências de plantas. Tomlinson observou, com respeito à Austrália, que dez por cento da flora foi introduzida desde o início dos assentamentos europeus, alcançando até duas vezes este valor quando se considera as regiões do sudeste do continente, onde a população é mais densa. ${ }^{17}$ No entanto, a Grã-Bretanha abriga proporções maiores de espécies não nativas, caso essa seja a medida para avaliar o fluxo das plantas. Um aparente desejo insaciável por aclimatar plantas exóticas e para hibridizar novos cultivares tornou a flora dos jardins britânicos a mais diversa do mundo. No século dezenove este movimento foi apoiado por uma grande produção de publicações, algumas lindamente ilustradas, muitas vezes por mulheres. ${ }^{18}$ Uma cultura pictórica exuberante ajudou a transformar plantas exóticas em objetos de interesse e desejo, da mesma forma como desenhos botânicos ajudaram a estimular a "tulipomania" na Holanda ${ }^{19} \mathrm{O}$ aumento da alfabetização e da cultura impressa foram essenciais para aumentar o interesse na Europa a respeito de jardins botânicos, história natural e transferências de plantas. Uma grande variedade de plantas foi absorvida, e desde então existem, em florestas, arboretos, espaços públicos e propriedades privadas. Também se manifestaram invasoras bem-sucedidas, como o rododentro, a trepadeira e uma espécie introduzida de verônica, que desafiam a suposição que a flora nativa Britânica é um habitat "fechado" que poucas espécies conseguem penetrar. ${ }^{20}$

Williamson, uma das principais autoridades britânicas sobre o tema das invasões biológicas, é cético a respeito de generalizações sobre as características de plantas invasoras, os ambientes que elas invadem e os ambientes nos quais elas se originam. ${ }^{21}$ Sua análise de síntese encontrou poucas evidências de que espécies de lugares específicos, como a Europa, se difundem com maior sucesso do que aquelas da América do Norte ou do hemisfério sul. Ele duvida que haja um perfil típico de uma invasora. Algumas invasoras bem-sucedidas têm um pequeno grau de reprodução. Seu sucesso pode estar mais relacionado com a mudança de habitat ou a ausência de predadores. Além disso, plantas podem até certo ponto alterar suas características biológicas e se hibridizar em novos ambientes: a Acacia longifolia e a Hakea gibbosa da Austrália produzem mais sementes na África do Sul do que em seu habitat de origem. ${ }^{22}$

Ele é igualmente cético em relação aos argumentos que enfatizam o papel do clima no favorecimento das transferências de biota. Ele reconhece que aquelas plantas que convivem com um leque mais amplo de temperaturas em seu ambiente doméstico parecem possuir um maior potencial de adaptação. No entanto, ele encontra uma "abundância de exceções" para questionar generalizaçôes intuitivas sobre combinações climáticas, vendo-as como "indicadores e prognósticos fracos” para explicar transferências bem-sucedidas. ${ }^{23}$ Existe potencialmente uma enorme área geográfica dentro da qual as espécies podem se mover. 
Elton sugeriu que quanto mais diversa for uma comunidade de plantas, mais ela está defendida de invasões. ${ }^{24}$ Revisando a literatura tradicionalmente estabelecida sobre a ecologia de ilhas, Williamson sugere que elas podem ser mais vulneráveis, pois parecem possuir um menor número de espécies nativas bem estabelecidas; seu isolamento tende a produzir um alto grau de endemismo e de especiação, mas, um baixo grau histórico de recepção. As ilhas, pode-se também considerar, eram importantes portos de passagem para as rotas de comércio dos antigos impérios marítimos europeus, sendo preferidas para o estabelecimento de plantaçôes ambientalmente destrutivas. No entanto, as ilhas podem não ser tão excepcionais. A colônia do Cabo, que tinha uma das vegetaçôes nativas mais diversificadas, foi altamente hospitaleira a novos cultivos e altamente sucessível às invasões, especialmente de arbustos e árvores exóticos. ${ }^{25}$ As florestas tropicais continentais são comumente tidas como resistentes às plantas invasoras, mas níveis baixos de presença de plantas invasoras podem ser atribuídos, ao menos em parte, tanto a fatores históricos quanto ecológicos. Williamson insiste que todos os sistemas são potencialmente propensos a sofrerem invasões. ${ }^{26}$

No entanto, de maneira parcial, Williamson também se mostrou aberto à ideia das transferências assimétricas. Sem se referir à tese de Crosby, ele concorda que "no século dezenove o padrão de colonização e comércio significou que as introduçôes vieram predominantemente da Europa". ${ }^{27}$ "Hoje em dia", ele prossegue, "o fluxo do comércio é bem mais amplamente difundido, e com maior velocidade, fazendo com que as espécies viajem em todas as direções." ${ }^{28}$ Nós já notamos que o fluxo das plantas pode não seguir simplesmente o fluxo do poder. Além disso, a principal fraqueza da abordagem de Williamson é que, apesar de admitir a importância da ação humana nas transferências de plantas, ele não desenvolve uma teoria ou metodologia que leve plenamente em conta essa ação. $O$ valor explicativo de seus modelos, dependentes que são das inter-relações entre as características das plantas e as comunidades naturais, é limitado. Ao atribuir a assimetria histórica ao comércio e ao imperialismo, Williamson deixa escapar, do campo da ecologia das populaçôes para o da história, uma importante faceta do fenômeno, defendendo de forma não intencional a necessidade de pesquisas sociais e econômicas detalhadas para entender as transferências, as invasões e seu impacto no longo prazo.

A ideia de uma assimetria histórica global na transferência de biotas continua muito atraente para os cientistas naturais e os historiadores ambientais, justificando um maior intercâmbio entre ambos. Seria interessante saber se espécies de plantas endêmicas em partes específicas do mundo, ou plantas invasoras em geral, realmente se reproduzem com maior velocidade do que outras, ou através de uma maior variedade de estratégias. Mas o mapa conceitual e geográfico de Crosby sobre a transferência de biotas é parcial, assim como a breve entrada de Williamson na história social também não ajuda muito. Os impérios sem dúvida facilitaram a transferência de plantas em um grau extraordinário, mas devemos ser cautelosos em aceitar um "bloco de poder" botânico ou um movimento assimétrico generalizado no longo prazo. O ponto mais evidente, no entanto, é a importância de se combinar fatores botânicos, ecológicos e sociais na análise dos fluxos de plantas e seus resultados.

\section{Ação humana: quem difunde plantas e por quê}

É essencial entender as propriedades das plantas quando analisamos seu alastramento e sua utilização, mas fazer isto não é o suficiente. Uma ampla variedade de textos fala sobre a atuação humana na transferências de plantas. A história socioeconômica de culturas específicas e dos complexos agrários que cresceram a partir delas produziu estudos muito esclarecedores: Salaman, sobre as batatas; Mintz, sobre o açúcar; Miracle, sobre o milho na África. ${ }^{29}$ Estudos comparativos deste tipo produzem oportunidades de esclarecer as interconexões entre propriedades das plantas, ecologias específicas e contextos socioeconômicos. "Biografias" de plantas que se tornaram importantes comercialmente, tais como a tulipa e o café, estão se multiplicando. ${ }^{30}$ Ao permitir uma abordagem tanto da história natural quanto da história social, esse gênero literário está ligado ao crescente interesse popular pela história da ciência. A história 
dos alimentos e dos jardins documenta a difusão de todos os tipos de plantas cultivadas. ${ }^{31}$ Uma literatura que se expande rapidamente, no âmbito acadêmico e popular, a respeito de viajantes científicos - incluindo ediçôes comentadas de suas obras - é outra fonte fértil para a história das plantas, mesmo quando este não é o foco principal. ${ }^{32}$ Classificar, identificar, coletar e transferir plantas foi frequentemente um dos principais motivos para as expedições científicas imperiais, de âmbito oficial e privado.

Uma das mais importantes estratégias quando se escreve sobre a história das plantas tem sido seguir os cientistas botânicos ocidentais e os desenvolvimentos institucionais na difusão de plantas economicamente relevantes. O livro Science and colonial expansion, de Lucile Brockway, focalizou principalmente os jardins botânicos de Kew e seus diretores - Joseph Banks, William Hooker e seu filho, Joseph -, na medida em que juntaram recursos e cultivaram conexôes globais para facilitar a transferência de plantas-chave: chá da China para a Índia; cinchona e borracha da América Latina para o sudeste da Ásia; sisal do México para o África Oriental. ${ }^{33} \mathrm{O}$ conhecimento botânico foi parte integrante da expansão colonial. Habilidades e instituições foram requeridas para identificar as plantas mais apropriadas, aclimatá-las em novos espaços e manejá-las para aumentar a produção. Novas tecnologias, como as caixas de Wardian - estufas protetoras em miniatura que também minimizavam a necessidade de água fresca melhoraram enormemente a chance de sobrevivência das plantas durante seu trânsito por mar e terra.

Brockway estava ciente de que o prestígio dos jardins Kew foi precedido por outros jardins botânicos, tanto na Europa como no caso de Leiden, ou no além-mar, alguns datando do século dezessete. Posteriormente, alguns autores têm desenvolvido análises mais refinadas sobre os mesmos. O argumento básico de Richard Grove sobre a importância da periferia colonial na criação de uma cultura de conservação da natureza pode ser adaptado aqui ao tema das inovações botânicas. Os jardins da Cidade do Cabo, controlados pela companhia holandesa das Índias orientais, "recorrendo a uma variedade global de plantas, algumas delas com objetivos especificamente medicinais ou comerciais, apresentavam uma imagem precisa do estado corrente do conhecimento botânico e de sua diligência". " Apesar de diferir da ênfase de Grove sobre a centralidade da periferia nas origens do pensamento ambiental, Richard Drayton concorda que os jardins botânicos coloniais se tornaram "centros de coleta de espécimes e de informação" em busca de plantas úteis ou raras. ${ }^{35} \mathrm{O}$ estabelecimento de Kew como uma instituição nacional dependeu muito da demanda do império britânico pela criação de um centro de conhecimento conectando os estabelecimentos coloniais, assim como de uma conjuntura particular de patronato real e desenvolvimento científico.

Os jardins botânicos privados na Itália - para experimentação médica e agrícola - precederam aqueles associados aos impérios holandês e inglês. Mauro Ambrosoli enfatizou a centralidade do conhecimento botânico na intensificação da agricultura na Europa e, especialmente, na difusão de cultivos de forragem no final da idade média e no início do período moderno. ${ }^{36} \mathrm{O}$ caso da lucena [variedade de pera], uma cultura perene de forragem, foi exemplar. Ela se estendeu gradativamente do Irã e Ásia central, através do litoral mediterrâneo, até o norte da Europa e, depois, nas colônias dos impérios europeus. Sua presença economizou mão de obra e facilitou uma maior concentração da agricultura mista numa época em que a intensificação requeria tração animal.

A ênfase de Ambrosoli no conhecimento e na produção de textos difere das preocupações de Crosby com relação ao processo biológico de difusão e deslocamento das plantas. Na medida em que seu objetivo explícito foi explorar as relações entre as plantas selvagens e cultivadas, e entre as espécies locais e exóticas, ele basicamente negligenciou as plantas exóticas que chegavam à Europa a partir do "novo mundo", concentrando-se no caso particular da lucena. ${ }^{37}$ Seu trabalho não espelha o conjunto das transferências de plantas para Europa que poderia se contrapor ao quadro histórico das transformaçôes na América produzido por Crosby.

Grove, Ambrosoli e Drayton adotam o enfoque da história das ideias. Drayton está bastante atento aos circuitos de patronato e produção de conhecimentos que apoiava Kew - especialmente no caso dos magnatas e proprietários de terras whig que, além de serem defensores do progresso imperial, de- 
senvolviam melhorias e experiências em suas próprias fazendas. Após os jardins serem transferidos da Coroa para o estado em 1840, ele argumenta, "o império informal de botânica econômica que Banks havia criado" se tornou "um instrumento burocrático formal para um governo colonial utilitário e eficiente". ${ }^{38}$ No entanto, o livro de Drayton é limitado para aqueles que buscam análises aprofundadas sobre botânica, plantas ou o impacto das transferências de plantas. Nele encontramos mais uma discussão sobre elites políticas do que sobre a botânica profissional ou sobre a febre de história natural popular observada no século dezenove e que impulsionou o interesse pela botânica.

A silvicultura, uma correlata especialização científica europeia, também promoveu transferências de plantas. Espécies europeias foram introduzidas em postos coloniais avançados desde o século dezessete, com o objetivo de prover madeira e lenha para combustível. As ilhas que serviam como postos de reabastecimento nas rotas marítimas imperiais foram logo desmatadas, estimulando, como resposta ao problema, o estabelecimento de plantações no século dezoito. O eucalipto australiano e os pinheiros do hemisfério norte foram identificados no século dezenove como espécies de crescimento rápido adequadas ao cultivo de plantações numa ampla variedade de assentamentos, do Uruguai à Califórnia, da cidade do Cabo à Índia. As técnicas de silvicultura científica desenvolveram-se no século dezoito na Alemanha e França, especialmente no caso de espécies locais que eram reproduzidas em contextos extraeuropeus, como na Índia. Posteriormente elas auxiliaram na transferência de uma ampla variedade de plantas exóticas para as colônias europeias. ${ }^{39}$ Os departamentos coloniais de silvicultura estatal, seguidos por empresas florestais privadas, ajudaram a transformar a vegetação de muitas zonas de alto índice de precipitação pluvial no império britânico.

Michal Osborne argumenta que a França e seu império no século dezenove, ao contrário dos impérios da Alemanha e da Grã-Bretanha, estavam no epicentro internacional do movimento de aclimatização. ${ }^{40} \mathrm{~A}$ Société Zoologique d'Acclimatation, formada em 1854 para promover "a introdução, aclimatação e domesticação de espécies úteis ou ornamentais de animais", estendeu suas atividades para a transferência de plantas, tornando-se no decorrer do segundo império uma das mais bem-sucedidas sociedade científicas nacionais. Ela era especialmente ativa na Argélia, onde Auguste Hardy, diretor do Jardin d'Essai em Argel, descreveu "o conjunto da colonização [como um] vasto feito de aclimatação". ${ }^{41}$ Esse jardim dedicava grande parte de seu orçamento à investigação da transferência de plantas asiáticas e latino-americanas para o norte da África, especialmente bambus, cana-de-açúcar da Indochina, abacate, café, cacau, e frutapão. O objetivo era identificar produtos tropicais coloniais que complementariam, ao invés de prejudicar, a economia agrícola francesa, substituindo a perda da colônia caribenha de Santo Domingo (Haiti).

Esses autores abriram áreas de pesquisa novas e estimulantes em história ambiental, história agrária e história da ciência. No entanto, os historiadores são frequentemente atraídos por instituições e documentos que deixam um rastro claro e facilmente inteligível. Ocorre que o foco no conhecimento formal e na história política e institucional, apesar de interessante em si mesmo, pode revelar apenas a ponta do iceberg no que se refere aos padrões de longo prazo nas transferências globais de plantas. As companhias, os colonos e os proprietários das plantações, em vez de cientistas e governos, frequentemente tomaram iniciativas que representaram desenvolvimentos institucionais. De fato, antes do final do século dezenove, a maioria dos estados coloniais britânicos tinham burocracias que contavam com orçamentos limitados e com pouca presença de especialistas. Storey argumentou que a ilha Maurício se tornou um centro da produção açucareira, na primeira metade do século dezenove, não em virtude dos funcionários britânicos e dos botânicos de Kew, mas sim devido ao interesse da elite franco-mauriciana, proprietária de terras, pela pesquisa sobre as plantas e sua reprodução. ${ }^{42}$

As narrativas ortodoxas sobre a "botânica como instrumento para a transferência de plantas", portanto, podem ser questionadas. Dean reescreveu a história do bem-sucedido desenvolvimento da borracha comercial na Malásia retirando a ênfase no papel de Kew e das açôes imperiais no sentido de reproduzir o material vegetal trazido do Brasil. Ele argumentou que o sucesso das plantações de borracha na Ásia se deveu muito à existência de um vírus que dificultava o desenvolvimento de uma economia de 
plantação no Brasil, habitat natural da planta. ${ }^{43}$ Assim como outros autores, ele também observou que coletores particulares de plantas procuraram adotar o mesmo processo com a cinchona, coletando as melhores sementes da planta. As tentativas de Kew, porém, resultaram em um fracasso desanimador.

$\mathrm{Na}$ África do Sul, o jardim botânico da cidade do Cabo desde o século dezessete, os estabelecimentos privados de von Ludwig no início do século dezenove e, subsequentemente, os jardins de Grahmstown e Durban, certamente ajudaram a difundir plantas exóticas. As autoridades florestais também tiveram um grande papel na plantação de árvores. ${ }^{44}$ Muitas dessas transferências essenciais, porém, foram feitas fora de contextos institucionais formais. Os colonos desenvolveram seus próprios conhecimentos, não profissionais, sobre tecnologias botânicas, que orientavam sua tomada de decisão sobre quais plantas exóticas eram úteis e desejáveis - e como elas poderiam ser cultivadas em um ambiente hostil. As peras espinhosas foram levadas às fronteiras mais longínquas do leste do Cabo, aonde um século depois se tornaram invasoras. Os cactos ramificados (Opuntia aurantiaca), introduzidos por agentes privados como uma planta de jardim, foram depois considerados uma peste ainda pior. ${ }^{45}$ Os colonos do Cabo ocidental ajudaram a criar um reino floral "mediterrâneo", um amálgama de plantas exóticas valorizadas pela avaliação de sua beleza e capacidade para se aclimatar. Estes complexos híbridos de plantas são observáveis em muitas zonas climaticamente semelhantes. A “colonização através da jardinagem” é uma atividade ubíqua no dia a dia das colônias de povoamento.

As relações informais foram ainda mais centrais no processo de transferência de plantas alimentares exóticas para sociedades nativas africanas. ${ }^{46}$ Em Madagascar, que se tornou uma colônia francesa muito depois da Argélia, os jardins botânicos governamentais se desenvolveram de forma relativamente tardia, apesar de já existirem jardins botânicos privados no final do século dezenove. No Jardim de Nampoana, perto de Fort Dauphin, por exemplo, foram feitas tentativas com muitas plantas de climas tropicais e temperados, incluindo o café e algumas árvores frutíferas. Mas a introdução e difusão de culturas agrícolas essenciais no sul de Madagascar - milho, mandioca, batata-doce e, desde o final de século dezoito, pera espinhosa - se realizou bem mais cedo, com poucos registros da sua ocorrência, exceto por informaçôes intermitentes em relatórios de viajantes ou negociantes europeus. ${ }^{47} \mathrm{~A}$ transferência do complexo de culturas típico do "sudeste da Ásia", baseado no cultivo do arroz, para as regiōes montanhosas de Madagascar, se realizou sob circunstâncias semelhantes.

Existe uma história para cada transferência, mesmo que especialistas não estejam envolvidos. Era normal as pessoas viajarem com sementes, assim como com animais domesticados. As mulheres pioneiras norte-americanas levavam-nas como parte de sua bagagem nas caravanas de carroças que seguiam em direção ao oeste. ${ }^{48}$ Os Afrikaners trekboers - frequentemente tidos como obcecados pelos seus animais domesticados - foram capazes de criar jardins culinários e pomares de frutas poucos anos depois de se assentarem nas fronteiras mais remotas do Cabo, onde quer que pudessem encontrar um suprimento de água adequado. Africanos que viajavam de volta da América, ex-escravos, levavam sementes de cacau em sua travessia pelo oceano Atlântico. ${ }^{49}$ Para ambos, colonos e povos indígenas, a sobrevivência na migração para novas áreas dependia de transferências bem-sucedidas.

Entre os historiadores da botânica, talvez Brockway seja a mais sensível ao sentido dessas histórias longas e informais. As sementes, diz ela, "têm sido um dos primeiro e mais preciosos artefatos culturais"..$^{50}$ Ela estava particularmente ciente do fato de Crosby ter caracterizado o "intercâmbio Colombiano", entre a Europa e as Américas, como tendo sido rápido e anterior em sua maior parte à especialização botânica. Como um historiador da alimentação observou, existiram "cereais imperialistas" bem antes de existir o imperialismo europeu. ${ }^{51}$ As redes comerciais árabes e indianas vêm sendo reconhecidas em relação aos cultivos alimentares, especialmente do açúcar. ${ }^{52}$

Uma análise das vias informais de conhecimento e experimentação é essencial para entender a atuação humana na transferência de plantas. Mas não se trata de algo tão fácil. Kreike revelou, através de um uso amplo da história oral, o papel de lavradores rurais na difusão da marula, árvore parcialmente aclimatada, para os distritos não nativos da Namíbia durante o século vinte. ${ }^{53}$ Resgatar as histórias de plan- 
tas em períodos anteriores é mais difícil, pelo menos para os historiadores ambientais que usam métodos convencionais de pesquisa. As referências em arquivos são muitas vezes confusas e não confiáveis. ${ }^{54}$ Uma combinação de metodologias deve ser adotada. Em um exemplo clássico de investigação, aspectos da história do milho ameríndio foram conectados através do uso de pesquisas nas áreas da antropologia, citologia e arqueologia, cada uma delas suprindo os dados que as demais não eram capazes. ${ }^{55}$

A enorme variedade de transferências torna difícil avaliar o papel da botânica e das ciências institucionalizadas. As plantas podem ser altamente móveis e a difusão de experimentos torna difícil fazer generalizações para além de estudos de caso específicos. As investigações sobre a história da botânica e das transferências promovidas por instituições formais são pouco apropriadas produzir informação relevante sobre culturas alimentares e de forragem, assim como sobre plantas de jardim - pelo menos antes do aparecimento dos viveiros comerciais (até agora pouco estudados). É igualmente pouco provável que elas possam esclarecer as transferências acidentais - pelo menos antes dos estados e cientistas botânicos se direcionarem para a supressão de ervas daninhas. A ciência penetra claramente em domínios antes dominados pela informalidade durante os séculos dezenove e vinte. Mas mesmo nesses períodos recentes as transferências acidentais podem ter predominado em escala global.

\section{Difusão não intencional, ervas daninhas e plantas invasoras}

A historiografia recente é mais forte a respeito do envolvimento formal em processos de transferência de plantas do que na atuação humana informal. Mas como avaliar esses dois processos contrapondo-os a um pano de fundo de transferências e difusôes acidentais e não intencionais? A dinâmica ecológica é claramente central nessa questão: sementes e plantas podem ser carregadas por correntes marítimas e de rios, pelo vento ou por animais. No entanto, a ação humana pode ser diretamente responsável pela transferência não intencional. Distúrbios ambientais socialmente provocados podem facilitar a disseminação de espécies específicas por outras forças naturais. A menção desse tema abre espaço para uma variedade de problemas e investigaçôes. Qual é a fronteira entre a ação humana informal e a difusão não intencional de plantas? Quando uma introdução aparentemente controlada se torna uma invasão não planejada e descontrolada? A literatura a respeito das invasões biológicas, assim como as análises sobre o conceito de ervas daninhas, é uma via eficaz para explorar algumas destas questôes.

As forças naturais não desapareceram com o surgimento recente de impérios, mas o relacionamento ecológico pode ser radicalmente reorganizado dentro das fronteiras imperiais. Crosby relaciona a difusão não intencional de plantas exóticas nas "neo-Europas" à introdução deliberada de raças de animais domesticados. A escala de crescimento dos animais introduzidos deve ser enfatizada: as populações de ovelhas nas grandes planícies do hemisfério sul, por exemplo, aumentou de talvez alguns poucos milhōes apenas na África do Sul em 1800, para 250 milhōes na Austrália, Nova Zelândia, Argentina, Uruguai e África do Sul, por volta de 1930; o gado, de uma quantidade inicial ainda menor, para cerca de 50 milhôes. Plantas como o carrapicho [erva daninha] europeu e o cardo, além de espécies de opuntia, foram disseminadas pelo gado. Os animais, portanto, transportavam sementes e cladódios [ramo verde e achatado, com forma e função semelhantes a uma folha], comiam e depositavam sementes, interferindo, assim, na vegetação nativa. Pode ser verdade que a introdução de plantas estrangeiras tenha sido particularmente rápida nestas regiões devido ao enorme crescimento da pecuária. A partir do momento em que uma nova semente fosse introduzida, a fauna selvagem local também poderia dispersá-la.

Os cultivos, como notou Van Sittert, "abriram espaço para um indesejado despejo de monstros a partir das culturas escolhidas pela humanidade para competir pelas terras recém-abertas" . ${ }^{6}$ Para a África do Sul, tem se sugerido que plantas exóticas foram frequentemente introduzidas de maneira acidental em conjunto com as sementes de espécies alimentares, até pelo fato da colheita em massa de grãos favorecer o alastramento não intencional de seus companheiros de viagem. ${ }^{57}$ Os khakibos (Applopappus $s p$., conhecidos, em certos regiōes, como tagete, ou cravo-de-defunto), onipresentes nos campos após o 
período de colheita das fazendas comerciais e dos pequenos lavradores da África, chegaram em conjunto com grãos alimentares por volta da guerra da África do Sul (1899-1902).

A jardinagem pode ser considerada como uma subárea das atividades de cultivo, mas normalmente produziu resultados diversos. Enquanto os cultivos com arado favoreceram as sementes trazidas acidentalmente, que germinavam em ciclos complementares, a jardinagem pode ter encorajado plantas que toleravam distúrbios ambientais e se reproduziam especialmente por meio do seu sistema de raízes. ${ }^{58}$ Por este motivo, sugere Van Jaarsveld, plantas originadas no leste da cidade do Cabo tornaram-se comuns nos vasos e jardins em escala global. O pastoreio, a agricultura com arado e a jardinagem suburbana parecem ter provocado diferentes tipos de introduções não intencionais. Novos padrões, em presença do fogo, também podem ajudar algumas espécies em detrimento de outras; ervas daninhas e de pasto podem elas mesmas se tornar um fator de aumento no risco de incêndios.

Ao analisar as transferências não intencionais pode ser pouco produtivo focalizar apenas os processos iniciais da sua introdução. As plantas que permaneceram confinadas em alguns poucos jardins, ou que entraram em extinção, podem oferecer insights interessantes a respeito das razóes do fracasso; mas a maioria das transferências apenas se tornam importantes, do ponto de vista histórico e ecológico, quando se disseminam. Alguns termos como "erva daninhas" ou "plantas úteis" apresentam categorias essenciais, porém problemáticas, quando se explora o processo acidental de disseminação. É interessante o fato de cientistas adotarem de forma não consciente alguns termos que são culturalmente carregados, tais como "invasoras" e "colonizadoras". O caso das peras espinhosas demonstra as dificuldades de fazer distinções claras diante dessas categorias e dos fatores humanos e não humanos na dinâmica de transferência de plantas específicas. Tanto na África do Sul quanto em Madagascar, as espécies de opuntia foram introduzidas intencionalmente. Em ambos os casos, certo grau de intervenção humana foi central no processo de seleção e propagação. No entanto, as peras espinhosas foram capazes de se reproduzirem rapidamente por meios sexuados ou assexuados (quando os cladódios suculentos se destacavam da planta), disseminando-se para regiōes onde não eram socialmente desejadas. Estas plantas, além disso, produziram deslocamentos na vegetação indígena.

Dadas estas dificuldades, como podemos fazer afirmações genéricas sobre transferências acidentais e invasões? Esses termos são confusos para os cientistas, e mais ainda para os leigos. ${ }^{59}$ Não se trata de um simples caso de dominar um vocabulário científico que difere daquele usado no cotidiano; os próprios cientistas não compartilham esse vocabulário. Nós precisamos, portanto, ser cuidadosos no entendimento do sentido que cada um atribui a cada conceito.

O uso feito por Elton do termo "invasão" corresponde aproximadamente ao uso popular, em parte pelo fato dele focalizar casos dramáticos de explosão populacional de uma espécie. ${ }^{60}$ Em contraste, a terminologia de Williamson é mais idiossincrática: uma "invasão biológica ocorre quando um organismo de qualquer tipo chega a um lugar que previamente estava fora do seu alcance". ${ }^{11}$ A preocupação de Williamson está em destacar o tema importante do fracasso na disseminação e torná-lo central em qualquer explicação. Ele argumenta que para compreender a dinâmica das invasões é preciso visualizar a dramaticidade dos fenômenos descritos por Elton no contexto de um universo mais amplo de exemplos.

As definições de Williamson podem também ser usadas na análise de culturas alimentares. Como observou Allard, "se a abundância e a disseminação através de muitos habitats diversos for um critério para o sucesso da colonização, muitas culturas alimentares podem ser tidas como colonizadoras notáveis e bem-sucedidas. A cevada, por exemplo, é uma cultura confiável em uma variedade de habitats, tendo seus limites de cultivo marcados por desertos, em uma extremidade, e pela tundra na outra extremidade". ${ }^{2}$ Em certo sentido, as culturas alimentares têm qualidades de invasoras por serem manejadas em função de sua força e adaptabilidade, ou seja, qualidades que garantem o seu sucesso para além dos limites de suas áreas de origem. Porém, classificá-las como invasoras parece paradoxal, pois quando contrastadas com "verdadeiras" invasoras, tais como o cardo e a pera espinhosa, os cultivos agrícolas permanecem muito mais dependentes das práticas agrárias humanas. $\mathrm{O}$ senso comum preferiria consi- 
derar as culturas alimentares ou espécies de plantações como invasoras apenas quando escapam dos domínios gerenciados de cultivo, aventurando-se em suas próprias rotas de ocupação. Cronk e Fuller concordariam: eles excluem o fator humano a priori, pois definem como planta invasora aquela que escapa com sucesso de seus domínios originais sem a assistência humana ${ }^{63}$ Mas, como no exemplo da pera espinhosa, essa definição pode ser demasiadamente restritiva.

Se os cientistas discordam quanto a definiçôes, eles tendem a concordar que "ervas daninhas", "invasoras", "pragas" podem ser mensuradas de maneira relativamente objetiva. Outros insistem na importância dos interesses econômicos e das percepções culturais na definição de que espécies são consideradas como úteis ou como ervas daninhas. É claro que as atitudes em relação à pera espinhosa no Madagascar e na África do Sul variam radicalmente. Fazendeiros brancos e mais ricos que criam animais domesticados, e que querem proteger suas pastagens de um invasor, mesmo que ele seja útil em algumas circunstâncias, agiram em favor do seu controle. Arrendatários brancos mais pobres, assim como trabalhadores negros, que comiam sua fruta, fermentavam-na, transformavam-na em xarope e usavam suas folhas como forragem e remédio, se consideravam beneficiados pela sua disseminação. No sul de Madagascar, durante a década de 1920, quando a pera espinhosa tornou-se um importante recurso para fazendeiros e pastores, a planta se transformou em tema de uma ardente controvérsia. Os debates coloniais foram muito além das considerações apenas de valor econômico, penetrando em questões morais e políticas como o propósito da colonização francesa e a perfectibilidade do homem. ${ }^{64}$

Os historiadores tendem a aceitar que a definição de erva daninha é subjetiva. O termo descreve plantas que não são consideradas úteis aos seres humanos, que "prevalecem sobre outras em solos perturbados" e que normalmente, mas de modo nenhum sempre, são exóticas às áreas onde são encontradas. ${ }^{65}$ Essa definição cultural permite que a mesma planta mude de status nos contexto do dinamismo histórico dos sistemas sócio-ecológicos. $\mathrm{O}$ amaranto domesticado originalmente na América se tornou uma erva daninha em outros lugares, enquanto o centeio tornou-se uma cultura alimentar. ${ }^{66}$ Valores culturais podem vir a competir com argumentos de utilidade. Os nacionalistas botânicos posicionamse contra as exóticas indesejáveis até mesmo aonde elas se tornam úteis. Em alguns sistemas culturais, as plantas ocupam posiçooes mais fluídas entre ervas daninhas e plantas cultiváveis. As "verduras" autossemeadas coletadas nas unidades de terra arável da África são um exemplo nessa direção. Em partes do sul de Madagascar, as peras espinhosas são classificadas simultaneamente como "cultivadas" e "selvagens". ${ }^{67}$ A literatura sugere que muitos ambientes agrícolas africanos são manejados tanto pela retirada, poda ou abandono das espécies nativas quanto pelo cultivo; e que as pessoas se adaptam às plantas que florescem naturalmente, por exemplo ao coletar lenha para uso doméstico.

As próprias categorias de "selvagem", "domesticado" e "cultivado" são problemáticas; não se pode assumir que outras sociedades classifiquem o mundo através de modos similares aos constructos culturais ocidentais. ${ }^{68} \mathrm{Na}$ América do Sul, Lévi-Strauss observou há meio século que "existem muitos estágios intermediários entre a utilização das plantas em seu estado selvagem e seu verdadeiro cultivo", um ponto subsequentemente desenvolvido por antropólogos, etnobotânicos e ecólogos históricos para as práticas ameríndias de agrossilvicultura em vários contextos. ${ }^{69}$ Esse ponto está também implícito na interpretação de Diamond sobre a domesticação como sendo um processo lento e gradual de seleção, em grande parte devido ao acaso, ocorrido na medida em que os caçadores-coletores recolhiam, comiam e gradualmente espalhavam quantidades maiores das espigas que mais tarde se tornaram grãos. No Equador, a visão Huaorami "a respeito do meio ambiente não discrimina entre o que é selvagem, domado ou domesticado, mas apenas entre o que cresce lenta ou rapidamente" ${ }^{70}$

Uma questão correlata é se existe alguma definição botânica ou característica fitológica para diferenciar as ervas daninhas. Neste ponto Ambrosoli concorda com Crosby de que "não existem diferenças botânicas entre espécies cultivadas e ervas daninhas, sendo o homem quem faz esta seleção". ${ }^{71}$ Mas uma posição construtivista pode obscurecer processos biológicos concretos que estejam ocorrendo. Como Ambrosoli observou, contradizendo sua afirmação anterior, plantas cultivadas desenvolvem carac- 
terísticas fitológicas distintas através da propagação, da experimentação e da fertilização cruzada. ${ }^{72} \mathrm{~A}$ passagem entre erva daninha e espécie cultivada pode não ser um caminho que esteja aberto ao tráfego em ambas as direções, já que o manejo agrícola das plantas normalmente diminui sua capacidade para competir na natureza sem que haja uma cuidadosa atenção humana. Tanto os historiadores quanto os cientistas tendem a ser inconsistentes nesse ponto. Se é importante reconhecer que termos como "erva daninha" são construções humanas, é igualmente importante desafiar as observaçóes vulgares de que não existem diferenças entre ervas daninhas e plantas cultivadas.

As definiçôes, assim como o seu embasamento epistemológico, ajudam a moldar questôes teóricas e metodológicas no estudo das transferências de plantas, e pedem um questionamento maior por parte de historiadores e cientistas naturais. Enquanto os antropólogos sociais estão bem cientes da importância das categorias locais, estas são frequentemente ignoradas ou simplesmente assumidas. Ambrosoli (e seu tradutor) glosam livremente termos vernáculos para o italiano e o inglês, tais como "selvagem" e "cultivado", sem indicar o quanto tais termos e seu uso podem diferir. "No século quinze", ele escreve, "as plantas eram classificadas como selvagens ou cultivadas aproximadamente da mesma forma como hoje." 73 A lucena é percebida em textos de alguns períodos como crescendo de maneira selvagem, quando um camponês, mais familiarizado com a ecologia e as práticas locais, poderia reconhecê-la como parcialmente cultivada. Ambrosoli fala sobre as plantas como sendo "rústicas", "crescendo espontaneamente", "no mato", sem perceber a complexidade das práticas agrícolas na periferia dos campos demarcados, ou nos interstícios dos sistemas agrários formais.

As definições também importam, como já argumentamos, se queremos ir mais além no objetivo de avaliar os fluxos das transferências e invasões de plantas: uma visão comum sobre a escala geográfica, a velocidade comparativa global das disseminações, e o impacto na vegetação e nas sociedades locais é crucial. Tal conhecimento, assim como as construçóes culturais, molda decisões políticas e permanece essencial nos debates sobre a biodiversidade e sobre o controle das ervas daninhas.

\section{Quando e por que as sociedades aceitam as transferências de plantas?}

No fundo de muitos dos pontos levantados nesse artigo aparece a questão de quando e por que as sociedades acolhem plantas exóticas. Perguntamos, por exemplo, até onde a dizimação dos ameríndios facilitou a transformação botânica: o ritmo teria sido diferente se tivessem permanecido demograficamente preponderantes e no controle de suas terras? No entanto, povos indígenas não necessariamente preferem plantas nativas. Experiências africanas, que não são contempladas nos modelos de fluxo assimétrico que examinamos, podem ser instrutivas. Esta seção conclusiva focaliza basicamente a África e um aspecto do leque de escolhas humanas - as inovações de culturas alimentares, incluindo a pera espinhosa. Não podemos generalizar com facilidade sobre as implicações das transferências de plantas como um todo, mas podemos discutir algumas das dinâmicas envolvidas.

Crosby, seguindo Boserup, sugere que pessoas são em sua maioria conservadoras, mas são compelidas a adotar plantas estrangeiras por necessidades práticas; por exemplo, por pressōes demográficas sob a terra. ${ }^{74}$ Com relação à África, alguns autores que desenvolvem uma posição anticolonialista enfatizam a resistência dos camponeses contra as introduçôes coloniais. Novas culturas comerciais, estimuladas ou impostas aos camponeses pelos governos, tiveram como consequência o aumento nas exigências por trabalho ou a transferência de mão de obra e de terras para a expansão das mesmas. Essas culturas, algumas vezes, contribuíram para o aparecimento de insegurança alimentar ou mesmo de fome. Na África Ocidental, as regióes interioranas de savana foram mais sujeitas a pagarem este preço do que as zonas florestais mais chuvosas. ${ }^{75}$ Houve uma resistência ao cultivo forçado de algodão em Moçambique por motivos semelhantes. ${ }^{76}$ A difusão gradual do milho e da mandioca foi relacionada com a má nutrição, pois estes cultivares americanos deslocaram as colheitas de alimentos básicos africanos e mais nutritivos como o sorgo e o painço. 
Fiona MacKenzie sugeriu que o tipo de milho preferido pelos funcionários agrícolas no Quênia eram inadequados para as condiçôes locais e que os camponeses, particularmente as mulheres, frequentemente preferiam suas próprias variedades mais antigas, que eram vistas como mais adaptadas e com sementes mais confiáveis. As iniciativas oficiais frequentemente sofriam resistência, como parte de um esforço mais amplo contra as regulamentações e intervenções coloniais no ambiente e na agricultura. A importância particular de sua análise está na ilustração das relaçôes de gênero como um elemento nas respostas e estratégias rurais. ${ }^{77}$ As implicações de tais argumentos é de que os africanos preferiam cultivar espécies familiares e que não se beneficiavam da inovação.

Alguns sistemas africanos também experimentaram períodos extensos de involução ou paralisia após períodos de rápida inovação. No leste da cidade do Cabo, por exemplo, os negros sul-africanos adotaram o arado, o transporte com bois, o milho, a aveia, o trigo, o feijão, a abóbora e as ovelhas produtoras de lã para que, entre 1820 e 1900, o seu sistema agrícola mudasse fundamentalmente. As culturas alimentares eram marcadas por uma ampla rede de troca que envolvia toda a região. Mas no decorrer das seguintes oito décadas, as inovações se tornaram menos comuns, apesar dos fazendeiros brancos vizinhos estarem cada vez mais ampliando e diversificando seu leque de cultivos e frutas. Este fechamento é difícil de explicar, mas coincide com o aumento da mão de obra migratória, com o acesso restrito aos mercados e com a redução na dependência de alimentos produzidos de maneira doméstica. A sobrevivência de formas comunais de posse podem ter dificultado o isolamento e o controle da terra para a introdução de novas culturas.

No entanto, como notado acima, os africanos adotaram muitas espécies americanas. Ao longo dos séculos elas passaram a fazer parte das principais culturas alimentares da África, sendo hoje vistas, muitas vezes, como nativas ou naturalizadas. É quase impossível conceber sistemas alimentares africanos sem o milho, a mandioca, a pimenta-malagueta, o tomate, os feijōes americanos e o amendoim, sem deixar de mencionar as peras espinhosas e o tabaco. Cultivos do Oriente como a cana-de-açúcar, os cítricos, as mangas, alguns tipos de arroz e, principalmente, plátanos e bananas, também têm sido importantes. Assim como, mais recentemente, vegetais como a cebola, o repolho e as batatas.

O milho é tão difundido e tão amplamente adotado pelos africanos como uma cultura nativa, que é difícil conceber que sua adoção e penetração subsequente no coração de muitos sistemas produtivos tenha sido forçada. As variedades mais antigas podem ter sido trazidas pelos comerciantes portugueses do século dezesseis, com o objetivo de aumentar as fontes de abastecimento dos navios negreiros. Mais recentemente os regimes coloniais incentivaram o seu cultivo. ${ }^{78}$ Mas a cultura não se disseminou menos no período anterior ao século dezenove, entre o tempo da escravidão e o domínio colonial. Ela apresentou muitas propriedades atraentes aos pequenos lavradores: uma espiga fechada que diminui o trabalho necessário para proteger as plantaçôes das aves predadoras. E também colheitas fartas, dadas certas condições do solo e da água, adequação ao cultivo com arado e ao armazenamento, resistência às doenças e um gosto claramente atrativo.

Culturas comerciais como o café e o cacau têm sido amplamente adotadas, trazendo considerável riqueza. Muitos autores, seguindo o famoso estudo de Polly Hill sobre o capitalismo rural entre os lavradores de cacau de Gana, têm celebrado tal inovação como uma crítica dos estereótipos coloniais sobre o atraso africano. ${ }^{79}$ As políticas de laissez-faire adotadas pelos britânicos em suas colônias na África Ocidental encorajaram o empreendedorismo africano. Na África Oriental, os governos coloniais eram mais restritivos em relação aos cultivos comerciais até a segunda guerra mundial. Consequentemente, o Quênia foi visto, cada vez mais, como um viveiro de inovação. A resposta dos preços é frequentemente citada como um fator-chave no processo de tomada de decisão, tanto nos modelos econômicos convencionais quanto nas análises radicais da inovação camponesa. Os preços para as culturas comerciais primárias, particularmente para o cacau, eram atraentes na virada do século vinte. Isso ajuda a explicar a rápida difusão de culturas comerciais na África Ocidental de então. 
Os incentivos dos preços ajudaram a explicar a inovação em casos importantes, mas esse relacionamento é raramente tão direto. Houve períodos fortes de expansão em momentos que não apresentavam preços favoráveis aos cultivos comerciais, especialmente no período entre guerras do século XX. Os produtores tinham que vender mais para poder pagar impostos e dívidas, assim como para comprar produtos importados e garantir a educação dos filhos. Boserup enfatizou a pressão demográfica e a erosão dos velhos sistemas agrários, ao invés dos preços em si, como um poderoso estimulo para a inovação. Um número muito limitado de comunidades rurais, em escala global, respondem aos picos nos preços das mercadorias quando adotam novos cultivares. O mais importante, talvez, seja o fato de uma vasta literatura antropológica e histórica sugerir que os modelos "econômicos" são demasiadamente simples. Africanos e chineses frequentemente falharam em responder aos incentivos dos preços devido aos seus construtos culturais tradicionais e sagrados, assim como por sua aversão ao risco e seu entendimento local dos processos ecológicos.

Berry argumenta que mesmo na África Ocidental, onde a promoção de novas culturas e oportunidades agrícolas foi mais permanente, existe apenas "uma ligação muito fraca com a resposta aos preços" ${ }^{80}$ Ela desenvolveu um modelo sofisticado de inovação agrícola que contextualiza as respostas aos preços em um complexo maior de múltiplas interaçôes sociais, econômicas e de gênero, tanto em nível local quanto externo. A ideia de capital social seria uma das vias para explicar a inovação agrícola: a disponibilidade de redes, comunidades, famílias extensas e grupos subordinados, assim como de capital e terras. Apesar de sua opção teórica ser atraente para antropólogos e historiadores, existem problemas em se invocar um leque tão vasto de relações. O que devemos entender como um alto nível de capital social? A sobrevivência de fortes redes de parentesco e comunidade pode também ser associada com a resistência às inovações. Estudos de caso têm ligado as conversões religiosas, e o individualismo, à inovação nas culturas alimentares. ${ }^{81}$

O capital, assim como o capital social, pode ter um grande papel na transferência de plantas alimentares. A existência de oportunidades prévias para a acumulação de capital, e para a construção de conhecimentos e habilidades empresariais, foram claramente importantes para a inovação de culturas na África Ocidental. Arhin sugere que a estrutura social de produção e os métodos organizacionais desenvolvidos através da experiência Ashanti do comércio de noz-de-cola e borracha selvagem serviram de base para a introdução e cultivo do cacau. ${ }^{82}$ Mas nem todo o acúmulo de capital e de conhecimento é necessariamente direcionado para a inovação de culturas. No sul do Madagascar, a explosão comercial da borracha não teve o mesmo resultado. A renda era investida em gado ou era usada na compra de produtos ocidentais importados, essencialmente tecidos, armas e espelhos. Depois de 1900, o pagamento de impostos coloniais sobre os indivíduos e sobre o gado se tornaram prioridades. Essas mesmas pessoas haviam acolhido a pera espinhosa um século antes. Em muitos contextos africanos, produtores de culturas comerciais bem-sucedidos escolheram a educação e empreendimentos não agrícolas para direcionar seus investimentos. Uma análise de base cultural seria essencial para explicar tais escolhas.

No caso da pera espinhosa, o preço teve certa relevância indireta para os agricultores comerciais da África do Sul, pois foram usadas como forragem nas secas, especialmente para os avestruzes durante o chamado feather boom entre 1880 e 1914. Tal qual a lucena na Europa, a opuntia foi incluída em uma dinâmica de intensificação generalizada da produção do pastoreio em partes de Madagascar e da África do Sul. No entanto, no longo prazo, a planta auxiliou tanto as culturas de subsistência quanto de exportação.

As abordagens que enfatizam fatores como terra e mão de obra relativamente livres, ao invés do simples estimulo externo dos preços, têm sido usadas para explicar a expansão das culturas comerciais de exportação. ${ }^{83}$ Elas também podem ser úteis quando colocadas em um contexto social, na discussão das inovações relacionadas com produção para o consumo local. As folhas de algumas variedades de opuntia podem ser comidas diretamente da planta. Mas o manejo dos cladódios para forragem, e especialmente para a preparação de frutas e folhas por manufaturas domésticas, exigia muito tempo. A opuntia se tornou 
uma planta de múltiplos usos em Madagascar e nas sociedades africanas que tinham pouco acesso a mercadorias manufaturadas. As propriedades inerentes de tais plantas eram de grande importância, representando, de certa forma, uma nova tecnologia que expandiu as fronteiras de cultivo e de assentamento.

Uma pergunta-chave a respeito das transferências de plantas é a da relação entre inovação e sistemas de conhecimento local. Isakandar e Ellen mostraram como as leis sagradas entre os Baduy, nas regiôes montanhosas de Java Ocidental, impediram o processo de inovação, proibindo a maioria das novas culturas e cultivares. No entanto, os Baduy estavam envolvidos com a prática da pequena agricultura itinerante em uma área de florestas degradadas e empobrecidas. ${ }^{84}$ Depois de uma resistência inicial, eles adotaram com sucesso a árvore leguminosa Paraserianthes falcataria, que reduzia o tempo de pousio e proporcionava alguma proteção contra o continuo esgotamento das velhas florestas ao seu redor. Os autores argumentam que esta inovação entre os Baduy, bem-sucedido e ecologicamente apropriado, estava fundada em um entendimento anterior sobre outras plantas que fixavam nitrogênio.

A ideia de que as plantas são introduzidas com enfoque na conservação do solo e da floresta provavelmente não pode ser generalizada, mesmo quando as pessoas têm uma longa familiaridade com a terra. Apesar do "ambientalismo dos pobres" ser um conceito valioso, é sempre importante especificar sob que condições ele é factível. ${ }^{85}$ A adoção do milho e da agricultura de arado na África, por exemplo, teve um impacto generalizado. Podemos também questionar se os agentes da inovação agrícola eram capazes de prever as implicaçóes ecológicas de longo prazo das suas introduçôes. A Paraserianthes falcataria é listada por alguns especialistas como sendo uma espécie invasora, e sua ampla utilização na agrossilvicultura tropical, assim como de outras árvores leguminosas de rápido crescimento, tem sido criticada. ${ }^{86} \mathrm{~A}$ pera espinhosa indubitavelmente competiu com e deslocou espécies nativas. Os seus espinhos, quando não tratados, podem ferir animais domesticados. Um benefício para uns foi uma praga para outros.

A inovação agrícola frequentemente requereu adaptações imprevisíveis de tecnologias e conhecimentos. Muitas transferências de plantas ocorrem em contextos "de fronteira", por exemplo, como quando pessoas migravam para lugares não familiares. Apesar de esses fenômenos híbridos sugerirem questóes interessantes sobre a interface entre padrões culturais e experimentação com plantas, eles têm sido em geral pouco investigados por antropólogos e estudiosos da etnobotânica, que tendem a interessar-se mais por povos indígenas e seus próprios conhecimentos sobre a flora nativa.

O paladar também pode ser um fator na transferência de plantas. Um aspecto desse tipo de tomada de decisão cultual envolve temas de preferência alimentar e de vício. ${ }^{87}$ Uma análise das mudanças no paladar ocidental constitui um elemento essencial para pensar algumas das transferências de plantas mais significativas, bem como sobre a formação das fronteiras de cultivos comerciais na África - açúcar, cacau, café e cannabis. O tabaco e o açúcar foram igualmente importantes na mudança dos padrōes de consumo africanos. A preferência de gosto pelo milho, por sua vez, em uma das suas muitas formas cozidas, é frequentemente expressada de forma anedótica. A pera espinhosa parece ser uma candidata menos óbvio para a apreciação cultural, apesar de africanos e malgaxes falarem positivamente das doces variedades frutíferas de opuntia, bem como de seu lugar na paisagem.

As sociedades africanas eram certamente abertas à introdução de plantas e muitos sistemas agrários do continente são baseados em plantas exóticas. $\mathrm{O}$ alcance que a pera espinhosa obteve como fruta de base para as atividades pastoris é uma prova. Neste contexto, a África não tem sido menos porosa às transferências de plantas do que outras partes do mundo, apesar da relativamente bem-sucedida resistência ao colonialismo de povoamento e da falta de grandes recursos demográficos. Pode-se argumentar que as plantas transferidas para a África auxiliaram na resistência e no aumento demográfico, fortalecendo a segurança alimentar. Também neste caso, a mercantilização relativamente tardia dos sistemas agrários não inibiu a absorção de novas espécies.

A história dos sistemas agrários africanos debilita ainda mais o modelo assimétrico de transferências de plantas do "velho" para o "novo" mundo. É difícil construir um argumento sobre os padrôes gerais 
de mudança da vegetação em um continente tão vasto. Existem claras diferenças entre, por exemplo, o norte da África e o oeste do Cabo, de um lado, e a floresta do Congo e o Kalahari, do outro. ${ }^{88}$ Os colonos europeus algumas vezes buscavam reproduzir paisagens familiares em lugares distantes ao introduzirem plantas europeias. Os colonos da parte ocidental do Cabo desenvolveram um vernáculo variado de tipos, valendo-se também de espécies locais e produzindo uma espécie de bricolagem botânica do Mediterrâneo (que também veio a incorporar plantas do Cabo). Na botânica, assim como na cultura, as sociedades coloniais frequentemente criaram formas novas e híbridas. ${ }^{89}$

No entanto, pode existir o argumento de que partes da África escaparam de transformaçôes botânicas radicais. A aridez, a densidade das florestas, a população rarefeita, a resistência a novas culturas alimentares e a alta proporção de terras para pastagens podem ter sido importantes nesse fenômeno. Se isso faz da África alguma coisa de excepcional é menos claro. Uma das fraquezas da síntese de Crosby está na sua falha em considerar a América do Norte como um todo. Uma grande parte da superfície do continente é formada pela tundra, pelo escudo canadense, pelas grandes pradarias e pelas Montanhas Rochosas, sendo que nenhum desses espaços foi especialmente poroso em termos botânicos. Seu modelo de imperialismo ecológico - ao menos com respeito às plantas - é bastante relevante para o litoral leste e para a Califórnia. A maior parte do interior da Austrália também foi parcialmente protegido por sua aridez. Pode ser mais útil, analiticamente falando, desagregar os grandes blocos geográficos do velho e novo mundo, ou dos continentes.

Este artigo explorou alguns caminhos na história das transferências de plantas, tecendo em conjunto perspectivas de várias disciplinas. Ele não pretendeu apresentar uma história completa, que seria uma tarefa muito mais complexa. No entanto, ele buscou oferecer um leque de questóes relevantes para novas pesquisas. Nós deliberadamente procuramos incluir na mesma análise cultivos agrícolas, plantas de jardim, ervas daninhas e plantas invasoras dentro do mesmo padrão de análise, pois muitas plantas - especialmente as espécies de opuntia, não se enquadram facilmente em uma dessas categorias.

$\mathrm{O}$ artigo levantou questões sobre a validade do conceito do imperialismo ecológico em relação ao poder das plantas europeias em si mesmas, e sobre a assimetria de longo prazo nas transferências de plantas. Nós argumentamos que a ação humana é certamente vital no entendimento dessas transferências e que o foco deveria estar tanto na atuação informal quanto na de base científica e institucional. Mas a elaboração de uma história global - assim como de histórias mais específicas - requer igualmente algum entendimento sobre as propriedades das plantas e, portanto uma incorporação mais sistemática da literatura científica. É somente através de tais estratégias interconectadas de pesquisa que um entendimento da história de plantas, como a pera espinhosa - uma planta exótica altamente difundida e com uma trajetória confusa e oscilante - pode ser alcançada.

\section{Notas}

${ }^{1}$ Jared Diamond, Guns, Germs and Steel: A Short History of Everybody for the Last 13,000 Years (London: Vintage, 1998).

${ }^{2}$ Alfred W. Crosby, Ecological Imperialism: The Biological Expansion of Europe 900-1900 (Cambridge: Cambridge University Press, 1986. Edição revista, Canto, 1993).

${ }^{3}$ Michael A. Osborne, Nature, The Exotic, and the Science of French Colonialism (Bloomington, Indianapolis: Indiana University Press, 1994), 166.

${ }^{4}$ Lucile Brockway, Science and Colonial Expansion: The Role of the British Royal Botanic Gardens (New York, London: Academic Press, 1979); Mauro Ambrosoli, The Wild and the Sown: Botany and Agriculture in Western Europe, 1350-1850 (Cambridge: Cambridge University Press, 1997); Richard Grove, Green Imperialism: Colonial Expansion, Tropical Island Edens and the Origins of Environmentalism, 1600-1860 (Cambridge: Cambridge University Press, 1995); Richard Drayton, Nature's Government: Science, Imperial Britain, and the 'Improvement' of the World (New Haven: Yale University Press, 2000).

${ }^{5}$ Ver a nota $\mathrm{n}^{\circ}$ 4; outros exemplos recentes incluem N. Jardine, J. A. Secord e E. C. Spary (eds.), Cultures of Natural History (Cambridge: Cambridge University Press, 1996); Stephen J. Pyne, Vestal Fire: An Environmental History, Told through Fire, of Europe and Europe's Encounter with the World (Seattle: University of Washington Press, 1997); Tom Griffiths e Libby Ro- 
bin (eds.), Ecology and Empire: Environmental History of Settler Societies (Edinburgh: Keele University Press, 1997); Paul Slack (ed.), Environments and Historical Change: the Linacre Lectures (Oxford: Oxford University Press, 1999); John McNeill, Something New Under the Sun: an Environmental History of the Twentieth Century (London: Allen Lane, 2000).

${ }^{6}$ Edward O. Wilson, Consilience: the Unity of Knowledge (London: Abacus, 1999).

${ }^{7}$ Crosby, Ecological Imperialism, 164.

${ }^{8}$ Crosby, Ecological Imperialism, 165.

${ }^{9}$ Edgar Anderson em Plants, Man and Life (London: Andrew Melrose, 1954), 19, observou esse ponto a respeito das plantas mediterrâneas na Califórnia.

${ }^{10}$ Quentin C. B. Cronk e Janice L. Fuller, Plant Invaders: The Threat to Natural Ecosystems (Royal Botanic Gardens, Kew and London: Chapman and Hall, 1995).

${ }^{11}$ Tim Flannery, The Future Eaters (London: Secker and Warburg, 1996) e "The Fate of Empire in Low and High-Energy Ecosystems", em Griffiths and Robin (eds.), Ecology and Empire.

${ }^{12}$ A ideia de uma vegetação nativa mais densa, como consequência da redução populacional dos ameríndios, é sugerida por Timothy Silver, A New Face on the Countryside: Indians, colonists and slaves in South Atlantic forests, 1500-1800 (Cambridge: Cambridge University Press, 1990).

${ }^{13}$ Crosby, Ecological Imperialism, segunda edição, xiv.

${ }^{14}$ A. W. Crosby, "The demographic effect of American crops in Europe”, em M. E. Sharpe (ed.) Germs, Seeds, and Animals: Studies in Ecological History (New York: Armonk, 1994), 148-166.

${ }^{15}$ Radcliffe Salaman, The History and Social Influence of the Potato (Cambridge: Cambridge University Press, 1949; edição revista, 1985).

${ }^{16}$ Sidney W. Mintz, Sweetness and Power: The Place of Sugar in Modern History (New York: Penguin, 1986).

${ }^{17}$ B. R. Tomlinson, "Empire of the Dandelion: Ecological Imperialism and Economic Expansion, 1860-1914", Journal of Imperial and Commonwealth History, 26, 2 (1998), 89.

${ }^{18}$ Lynn Barber, The Heyday of Natural History, 1820-1870 (London: Jonathan Cape, 1980); W. Blunt, The Art of Botanical Illustration (London: Collins, 1950); Jardine, Secord and Spray (eds.) Cultures of Natural History.

${ }^{19}$ Anna Pavord, The Tulip (London: Bloomsbury, 1999).

${ }^{20}$ Sobre habitats "abertos" e "fechados", ver Anderson, Plants, Life and Man, 127; ver também Charles Elton, The Ecology of Invasions by Animals and Plants (London: Methuen, 1958; republicada em 1977).

${ }^{21}$ Mark Williamson, Biological Invasions (London: Chapman and Hall, 1996).

22 Williamson, Biological Invasions, 54.

${ }^{23}$ Williamson, Biological Invasions, 70.

${ }^{24}$ Elton, The Ecology of Invasions.

${ }^{25}$ I. A. W. MacDonald, F. J. Kruger e A. A. Ferrar (eds.), The Ecology and Management of Biological Invasions in Southern Africa (Oxford University Press, Cape Town, 1986).

${ }^{26}$ Williamson, Biological Invasions, 77.

${ }^{27}$ Williamson, Biological Invasions, 30; ver também F. di Castri, "History of biological invasions with special emphasis on the old world”, em J. A. Drake, H. A. Mooney, F. di Castri, R. H. Groves, F. J. Kruger, M. Rejmánek e M. Williamson (eds.), Biological Invasions: A Global Perspective (Chichester, UK: John Wiley \& Sons, Chichester, 1989), 1-30.

${ }^{28}$ Williamson, Biological Invasions, 30.

${ }^{29}$ Radcliffe Salaman, Influence of the Potato; Mintz, Sweetness and Power; Marvin P. Miracle, Maize in Tropical Africa (Madison: University of Wisconsin Press, 1966).

${ }^{30}$ Pavord, The Tulip; Mark Pendergrast, Uncommon Grounds: The History of Coffee and How It Transformed Our World (New York: Basic Books, 1999); Mark Kurlansky, Cod: a Biography of the Fish that Changed the World (London: Jonathan Cape, 1998), uma das publicações mais bem sucedidas neste campo.

${ }^{31}$ Maguelonne Toussaint-Samat, A History of Food (Oxford: Blackwell, 1994); S. G. Harrison et.al., The Oxford Book of Food Plants (London: Peerage Books, 1985); Kenneth F. Kiple e K.C Ornelas (eds.), The Cambridge World History of Food (Cambridge: Cambridge University Press, 2000).

${ }^{32}$ Mary Lousie Pratt, Imperial Eyes: Travel Writing and Transculturation (London: Routledge, 1992); Peter Raby, Bright Paradise: Victorian Scientific Travellers (London: Chatto and Windus, 1996).

${ }^{33}$ Brockway, Science and Colonial Expansion.

${ }^{34}$ Grove, Green Imperialism, 93. 
${ }^{35}$ Drayton, Nature's Government, 122.

${ }^{36}$ Ambrosoli, The Wild and the Sown.

${ }^{37}$ Ambrosoli, The Wild and the Sown, 109.

${ }^{38}$ Drayton, Nature's Government, 160.

${ }^{39}$ Richard Grove, Vinita Damodoran e Satpal Sangwan (eds.), Nature and the Orient: the Environmental History of South and Southeast Asia (Delhi: Oxford University Press 1998).

${ }^{40}$ Osborne, Science of French Colonialism.

${ }^{41}$ Auguste Hardy, "Importance de l'Algérie comme station d'acclimatation”, extraído de L'Algérie agricole, commerciale, industrielle (Paris, 1860), 7. Cited 145, n.1.

${ }^{42}$ William Storey, Science and Power in Colonial Mauritius (Rochester: University of Rochester Press, 1997).

${ }^{4}$ Warren Dean, Brazil and the Struggle for Rubber: A Study in Environmental History (Cambridge: Cambridge University Press, 1987).

${ }^{44}$ G. Shaughnessy, "A case study of some woody plant introductions to the Cape Town area", em MacDonald et. al., Biological Invasions in Southern Africa, 37-43.

${ }^{45}$ W. Beinart, The Rise of Conservation in South Africa: Settlers, Livestock and the Environment, 1770-1950 (Oxford: Oxford University Press, 2003), capítulo 8.

${ }^{46}$ M. Miracle, Agriculture in the Congo Basin: Tradition and Change in African Rural Economy (Madison: University of Wisconsin Press, 1966); Jan Vansina, Paths in the Rainforest (Madison: University of Wisconsin Press, 1990).

${ }^{47}$ Karen Middleton, “The Ironies of Plant Transfer”, em W. Beinart e J. McGregor (eds.), Social History and African Environments (Oxford: James Currey, 2003).

${ }^{48}$ Annette Kolodny, The Land Before Her: Fantasy and Experience of the American Frontiers, 1630-1860 (University of North Carolina Press, Chapel Hill, 1984).

${ }^{49}$ William Gervase Clarence-Smith e François Ruf (eds.), Cocoa Pioneer Fronts since 1800: The Role of Smallholders, Planters and Merchants (London: Macmillan, 1996).

${ }^{50}$ Brockway, Science and Colonial Expansion, 36.

${ }^{51}$ Toussaint-Samat, A History of Food, 130.

${ }^{52}$ Mintz, Sweetness and Power.

${ }^{53}$ Emmanuel Kreike, "Hidden Fruits: a Social Ecology of Fruit Trees in Namibia and Angola, 1880s-1990s", em Beinart e McGregor (eds.), Social History and African Environments.

${ }^{54}$ Miracle, Maize in Tropical Africa, 60; Ambrosoli, The Wild and the Sown.

${ }^{55}$ Anderson, Plants, Man and Life, 99-104.

${ }^{56}$ Lance van Sittert, “The Seed Blows About in Every Breeze: Noxious Weed Eradication in the Cape Colony, 1860-1909”, Journal of Southern African Studies, 26, 4 (2000), 655-674.

${ }^{57}$ MacDonald et. al., Biological Invasions in Southern Africa, 26.

${ }^{58}$ Esta ideia é sugerida em Ernst van Jaarsveld, "Shaped by Suffering: Veld and Flora", Journal of the Botanical Society of South Africa, 87, 1 (2001), 16-19 através de uma breve comparação entre as plantas do leste e do oeste do Cabo. Gerânio, crássula, espada-de-são jorge, clorófito são citadas como exemplos. Sima Eliovson, South African Wild Flowers for the Garden (Cape Town: Howard Timmins, 1960).

${ }^{59}$ E. Mayr, "Introduction”, em H. G. Baker e G. L. Stebbins (eds.), The Genetics of Colonizing Species (New York: Academic Press, 1965).

${ }^{60}$ Elton, The Ecology of Invasions, 1, 15, 61.

${ }^{61}$ Williamson, Biological Invasions, 1-2, 30.

${ }^{62}$ R. W. Allard, “Genetic Systems Associated with Colonizing Ability in Predominantly Self-Pollinated Species”, em Baker e Stebbins (eds.), The Genetics of Colonizing Species, 49.

${ }^{63}$ Cronk e Fuller, Plant Invaders, 1.

${ }^{64}$ Karen Middleton, "Who killed 'Malagasy Cactus'? Science, Environment and Colonialism in Southern Madagascar (1924-1930)", Journal of Southern African Studies, 25, 2 (1999), 215-248.

${ }^{65}$ Crosby, Ecological Imperialism, 149.

${ }^{66}$ Para a combinação entre culturas agrícolas e ervas daninhas, ver J. R. Harlan e J. M. J. de Wet, "Some thoughts about weeds", Economic Botany 19 (1965), 16-24.

${ }^{67}$ Middleton, "The Ironies of Plant Transfer". 
${ }^{68}$ Elizabeth Croll e David Parkin, "Cultural understandings of the environment", em E. Croll e D. Parkin (eds.), Bush Base, Forest Farm: Culture, Environment and Development (London: Routledge, 1992).

${ }^{69}$ Claude Lévi-Strauss, "The use of wild plants in tropical South America”, em J. Steward (ed.), Handbook of South American Indians, vol. 6, Physical Anthropology, Linguistics, and Cultural geography of South American Indians (Washington, D. C.: Smithsonian Institution Press, 1950), 465. William Balée, “The Culture of Amazonian Forests”, em Darrell Posey e Willaim Balée (eds.), Resource Management in Amazonia: Indigenous and Folk Strategies Advances in Economic Botany, vol. 7 (Bronx: New York Botanical Garden), 1989, 1-21; W. Balée, "Indigenous transformation of Amazonian forests: An example from Maranhão, Brazil”, L'Homme, 33 (1993), 231-254; D. Posey, "Indigenous management of tropical forest ecosystems: the case of the Kayapó Indians of the Brazilian Amazon”, Agroforestry Systems, 3 (1985), 139-158.

${ }^{70}$ Laura Rival, "Domestication as a historical and symbolic process: wild gardens and cultivated forests in the Ecuadorian Amazon”, em William Balée (ed.), Advances in Historical Ecology (New York: Columbia University Press, 1995), 244.

${ }^{71}$ Ambrosoli, The Wild and the Sown, 2.

${ }^{72}$ Ambrosoli, The Wild and the Sown, 102, 110.

${ }^{73}$ Ambrosoli, The Wild and the Sown, 96.

${ }^{74}$ Crosby, Germs, Seeds; Ester Boserup, The Conditions of Agricultural Growth: the Economics of Agrarian Change under Population Pressure (London: Allen and Unwin, 1965); ver também Mary Tiffen, Michael Mortimore, e Francis Gichuki, More People, Less Erosion: Environmental Recovery in Kenya (Chicester: John Wiley \& Sons, 1994).

${ }^{75}$ Michael Watts, Silent Violence: Food, Famine and Peasantry in Northern Nigeria (Berkeley: University of California Press, 1983).

${ }^{76}$ Allen Isaacman, Cotton is the Mother of Poverty: Peasants, Work, and Rural Struggle in Colonial Mozambique 1938-61 (Oxford: James Currey, 1996); Allen Isaacman e Richard Roberts (eds.), Cotton, Colonialism and Social History in Sub-Saharan Africa (Oxford: James Currey, 1996).

77 A. Fiona D. MacKenzie, Land, Ecology, and Resistance in Kenya, 1880-1952 (International Africa Institute: Edinburgh University Press, 1998).

${ }^{78}$ Miracle, Maize in Tropical Africa.

${ }^{79}$ Polly Hill, Studies in Rural Capitalism in West Africa (Cambridge: Cambridge University Press, 1970); A Hopkins, An Economic history of West Africa (London: Longman, 1973); Robert H. Bates, Essays on the Political Economy of Rural Africa (Cambridge: Cambridge University Press, 1983); Michael Mortimore, Roots in the African Dust: Sustaining the Drylands (Cambridge: Cambridge University Press, 1998).

${ }^{80}$ Sara Berry, No Condition is Permanent; The Social Dynamics of Agrarian Change in Subsaharan Africa (Madison: University of Wisconsin Press, 1993).

${ }^{81}$ David J. Parkin, Palms, Wine and Witnesses: Public Spirit and Private Gain in an African Farm Community (London: Chandler, 1972).

${ }^{82}$ Raymond Dumett, "The Rubber Trade of the Gold Coast and Asante in the Nineteenth Century: African Innovation and Market Responsiveness", Journal of African History, 12, 1 (1971), 79-101; Kwame Arhin, "The Ashanti Rubber Trade with the Gold Coast in the Eighteen-Nineties", Africa, 42, 1 (1972), 32-43; Berry, No Condition is Permanent.

${ }^{83}$ Hopkins, History of West Africa; Clarence-Smith e Ruf (eds.), Cocoa Pioneer Fronts.

${ }^{84}$ Johan Iskandar e Roy F. Ellen "The Contribution of Paraserianthes (Albizia) falcataria to Sustainable Swidden Management Practices Among the Baduy of West Java", Human Ecology, 28 (2000), 1-17.

${ }^{85}$ Henry Bernstein e Philip Woodhouse, “Telling Environmental Change Like It Is?”, Journal of Agrarian Change, 1 (2001), 283324; Ramachandra Guha e J. Martinez Alier, Varieties of Environmentalism: Essays North and South (London: Earthscan, 1997).

${ }^{86}$ Cronk e Fuller, Plant Invaders.

${ }^{87}$ M. Douglas, "Deciphering a meal”, Daedalus, 101 (1972): 61-82; John Brewer e Roy Porter (eds.), Consumption and the World of Goods (London: Routledge, 1993); Para o caso das flores, ver Pavord, The Tulip e Jack Goody, The Culture of Flowers (Cambridge: Cambridge University Press).

${ }^{88}$ J. Rousseau, "Des colons qui apportent avec eux leur ideologie”, em Jacques Barrau e Jacqueline Thomas (eds.), Langues et techniques, nature et société, vol 2. (Paris: Klincksieck, 1972).

${ }^{89}$ Ann Laura Stoler, "Rethinking Colonial Categories: European Communities and the Boundaries of Rule", Comparative Studies in Society and History, 31 (1989), 134-161; Ann Laura Stoler e Frederick Cooper (eds.), Tensions of Empire: Colonial Cultures in a Bourgeois World (Berkeley: University of California Press, 1997). 


\title{
RESUMO
}

Este artigo explora algumas rotas dentro da história da transferência de plantas, especialmente durante o periodo do imperialismo europeu. Tenta extrair conhecimento de diferentes campos de pesquisa, que geralmente não estão justapostos, tecendo em conjunto perspectivas advindas de disciplinas contrastantes. Não pretende oferecer uma história completa, pois tal seria uma tarefa muito mais complexa. Tentamos incluir deliberadamente plantas cultivadas para a agricultura, plantas de jardim, ervas daninhas e plantas invasoras na mesma estrutura de análise, pois é dificil definir algumas espécies apenas dentro de uma dessas categorias culturalmente construidas. $O$ artigo desenvolve três pontos principais. Primeiramente, ele levanta questôes sobre o padrão assimétrico de transferência de plantas durante o periodo imperialista, consequentemente desafiando algumas das proposiçōes presentes no livro Ecological imperialism, de Alfred Crosby. Em segundo lugar, avaliamos a literatura recente com relação à história da botânica e das instituiçôes botânicas e sugerimos que uma área mais ampla de atuação humana necessita ser considerada, assim como as transferências acidentais, se quisermos mapear e compreender os movimentos globais das espécies de plantas. Em terceiro lugar, argumentamos que, na busca de generalizações sobre os padröes de transferência, os cientistas têm se concentrado em demasia nas propriedades das plantas e os historiadores, no entendimento das instituiçōes politicas e econômicas. A construção de uma história global, assim como de histórias de plantas específicas, requer uma combinação de percep̧̧ões e pesquisas advindas das ciências exatas, sociais e humanas.

Palavras-chave: transferências de plantas, história ambiental, imperialismo ecológico.

\begin{abstract}
This paper explores some routes into the history of plant transfers, especially during the period of European imperialism. It attempts to draw on different bodies of research, which are not usually juxtaposed, and weave together perspectives from contrasting disciplines. It does not pretend to offer a history, which is a much more complex task. We have deliberately tried to include cultivated crops, garden plants, weeds and plant invaders within the same frame of analysis, because it is so difficult to define some species within any one of these culturally constructed categories. The paper develops three main points. Firstly, it raises questions about the asymmetrical pattern of plant transfers during imperialism, thus challenging some of the propositions offered in Crosby's Ecological Imperialism. Secondly, we evaluate recent literature on the history of botany and botanical institutions and suggest that a broader range of human agency needs to be considered, as well as accidental transfers, if the global trajectories of plant species are to be mapped and comprehended. And thirdly, we argue that in pursuit of generalizations about patterns of transfer, scientists have concentrated too much on plant properties, and historians on understanding political economy or institutions. A global history, as well as particular plant histories, requires a combination of insights and research from sciences, social sciences and humanities. Keywords: plant transfers, environmental history, ecological imperialism.
\end{abstract}

